\title{
CLASTS WITH STOSS-LEE FORM IN LODGEMENT TILLS: A DISGUSSION
}

\section{By Johannes KRüGER}

(Department of Geomorphology, Geographical Institute, University of Copenhagen, Haraldsgade 68, DK-2100 Copenhagen Ø, Denmark)

Abstract. Clasts modified by glacial erosion are described from lodgement tills in front of the glacier Mýrdalsjökull, south Iceland. Many clasts show modification of their lower surfaces in the same way as their upper ones. However, the lower surfaces have a smoothed down-glacier face and a truncated up-glacier face, which is the opposite orientation to that of the upper surfaces. This so-called double stoss-lee form is interpreted as a response to basal transport over abrading materials, following deposition of the clast and succeeded by glacial erosion. It is suggested that clasts with a double stoss-lee form are a diagnostic criterion for subglacial deposition by lodgement. Furthermore, the distribution and orientation of clasts with a stoss-lee form was investigated on a ground-moraine surface. $17.3 \%$ of 2199 clasts with an $a$-axis diameter $>30 \mathrm{~cm}$ had a stoss-lee form. The proportion of clasts with their smoothed ends facing up-glacier within $\pm 22.5^{\circ}$ of the ice-flow direction was $72.7 \%$. Thus, the preferred stoss-side orientation is closely related to the ice movement and indicates the direction from which the ice came. Only $11.7 \%$ of boulders with a divergent stoss-side orientation are located in connection with annual moraines. It is suggested that such boulders have mainly been re-deposited beneath the ice and not at the ice front by minor advances of the glacier.

RÉsumé. Des blocs avec des formes de roches moutonnées dans les dépôts glaciaires: une discussion. Des blocs façonnés par l'érosion glaciaire sont décrit à partir de dépôts sur le front du glacier Mýrdalsjökull, Islande du Sud. De nombreux blocs montrent des modifications de leur base aussi bien que de leur sommet. Cependant la base présente une face polie vers l'aval du glacier et une face tronquée vers l'amont, ce qui est le contraire de la surface supérieure. Cette double forme de roche moutonnée est interprêtée comme une réponse au transport à la base sur des matériaux abrasifs, suivant le dépôt de blocs et la reprise par l'érosion glaciaire. On propose que ces blocs à double forme de roches moutonnées constituent un critère pour le diagnostic d'un dépôt sous-glaciaire en place. D'autre part, la répartition et l'orientation des blocs avec des formes moutonnées ont été recherchées à la

\section{INTRODUCTION}

Many clasts embedded in ground moraine in front of present-day glaciers occur in a characteristic position with a smoothed, often bullet-nosed, upglacier termination and an abruptly truncated downglacier termination (Fig. 1). It is suggested that this stoss-lee form is due to subglacial erosion after lodgement of the boulder, and the smoothed stoss-side orientation indicates the direction from which the ice came (0kko, 1955; Boulton, 1978; Krüger, 1979). Recently, Sharp (1982) demonstrated how size and lithology of clasts may influence the extent to which the above erosional modification occurs. However, Sharp (1982, p. 478) pointed out that in his study area (the forefield of the glacier Skálafellsjökull, south-east Iceland) the lower surfaces of boulders had not been smoothed and streamlined in the same way as their upper surfaces. Furthermore, he mentioned ( $p$. 480) that clasts with a stosslee form, but with a divergent orientation relative to the ice-flow direction, had probably been re-

deposited by minor advances of the ice front responsible for constructing small push moraines.

This note directs attention to (1) modification of the lower surfaces of clasts in the same way as their upper surfaces, and (2) discusses the orientation of clasts with a stoss-lee form.

The study site is the ground moraine in front of the northern margin of the glacier Mỹrdalsjökull, surface d'une moraine. $17,3 \%$ des 2199 blocs d'axe principal d'une longueur $>30 \mathrm{~cm}$ présentent une forme de roche moutonnée. La proportion des blocs présentant leur face lisse vers l'amont du glacier, à $\pm 22,5^{\circ}$ de l'écoulement de la glace, s'élevait à $72,7 \%$. Ainsi l'orientation préférentielle du moutonnage est fortement correlée au mouvement de la glace et indique d'où vient le glacier. Seulement $11,7 \%$ des roches moutonnées s'écartant de cette orientation sont situés en rapport aux moraines annuelles. On suggère que de telles roches ont principalement été redéposées sous la glace et non au front à la suite d'avances secondaires du glacier.

Zusammenfassung. Blockschutt mit Stoss- und Lee-Formen in Grundmoränenablagerungen: eine Diskussion. Aus Grundmoränenablagerungen vor der Front des Mýrdalsjökull in Südisland wird Blockschutt beschrieben, der durch glaziale Erosion bearbeitet wurde. Viele Blöcke zeigen an ihrer Unter- und Oberseite gleiche Bearbeitungsspuren. Jedoch besitzen die Unterseiten gletscherabwärts ein geglättetes, gletscheraufwärts dagegen ein verstümmeltes Aussehen, während die Oberseiten entgegengesetzt orientiert sind. Diese sog. doppelte Stoss- und Lee-Form lässt sich als Auswirkung eines Transports über abschlaffendes Material am Untergrund deuten, welcher der Ablagerung des Blockes mit anschliessender Bearbeitung durch glaziale Erosion folgte. Blockschutt mit doppelter Stoss- und Lee-Form sollte als diagnostisches Anzeichen für eine subglaziale Ablagerung durch Anhäufung betrachtet werden. Weiterhin wurde die Verteilung und Orientierung von Blockschutt mit Stoss- und Lee-Form auf der Oberfläche einer Grundmoräne untersucht. $17,3 \%$ von 2199 Blöcken mit einer $a$ Achsenlänge $>30 \mathrm{~cm}$ hatten eine Stoss- und Lee-Form. Der Anteil von Blöcken mit geglätteten Enden gletscheraufwärts innerhalb von $\pm 22,5^{\circ}$ der Fliessrichtung war $72,7 \%$. Die bevorzugte Orientierung der Stoss-Seite ist also eng mit der Eisbewegung verbunden und zeigt die Richting an, aus der das Eis kam. Nur 11,7\% der Blöcke mit einer divergenten Orientierung der Stoss-Seite liegen im Verbund mit Jahresmoränen. Es wird angenommen, dass solche Blöcke hauptsächlich unter dem Eis und nicht an der Eisfront durch kleinere Vorstösse des Gletschers abgelagert wurden.

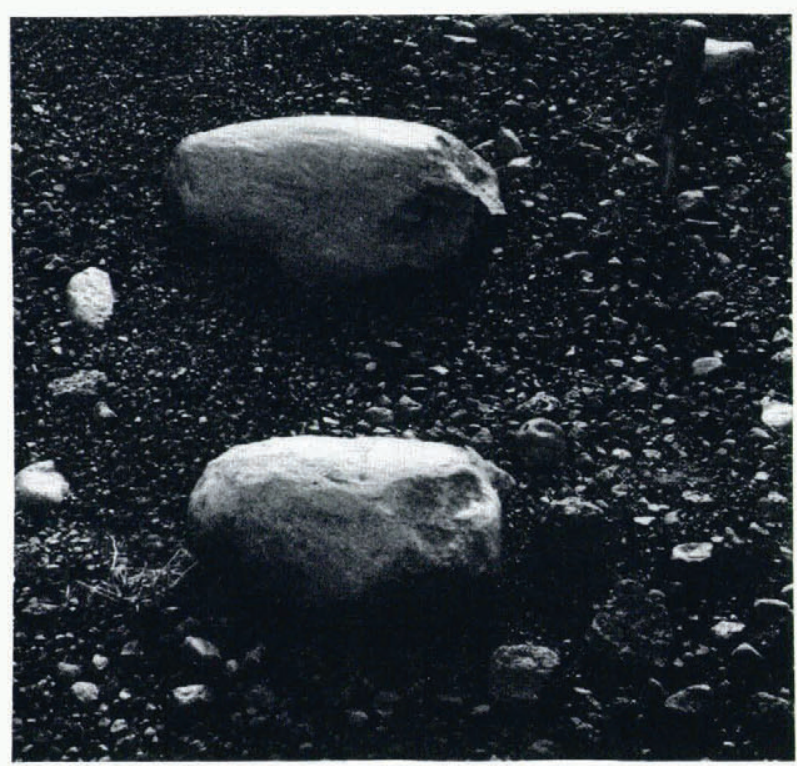

Fig. 1. Clasts with a stoss-lee form embedded in ground moraine in front of Mÿrdalsjökull, Iceland.

Glacier flow is from left to right. (Photograph 1982.) 
south Iceland (1at. $63^{\circ} 47^{\prime} \mathrm{N}$. , long. $18^{\circ} 55^{\prime} \mathrm{W}$. ), which has been deglaciated within the last 40 years.

\section{CLASTS WITH A DOUBLE STOSS-LEE FORM}

The survey at Mýrdalsjökull reveals that many clasts with a stoss-lee form also show a significant modification of their lower surfaces (henceforth termed a "double stoss-lee form"). It should be noted that the orientation of the stoss-lee form on the lower surfaces is opposite to that of the upper ones; the lower surfaces have a smoothed down-glacier face and a truncated up-glacier face.

A generalized picture of the formation of the double stoss-lee form is suggested in Figure 2. The lower down-glacier face of a clast which moves over abrading, al ready deposited till materials during
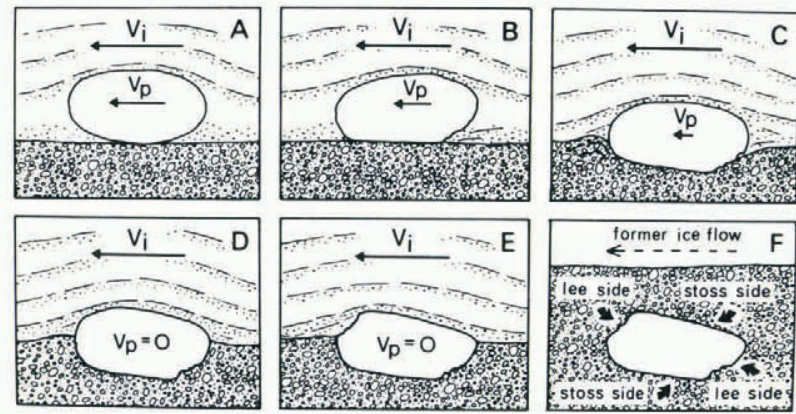

Fig. 2. Formation of double stoss-lee forms by subglacial lodgement. Glacier flow is from right to left. $V_{j}$ and $V_{p}$ are the velocity of basal ice and clast in basal transport, respectively.

A. Clast in traction over a bed of already deposited till. B. Modification of the lower surfaces by movement of the clast over the abrading till bed. C. Progressive lodgement of the clast against deformable till, which is ploughed up in front of the moving clast. D. The clast has become firmly lodged. E. Modification of the upper surfaces by erosion by overriding debris-laden ice. F. The end product: a clast with double stoss-lee form buried by further lodgement of debris.

basal transport is abraded and streamlined, while the lower up-glacier face is unaffected by erosion or is shaped by fracture. After deposition of the clast by ploughing into the till bed, but before the clast becomes buried by lodgement of debris, the abrading debris-laden glacier sole passes over its upper surface. By this means the upper up-glacier face is smoothed and streamlined, while the upper down-glacier face becomes truncated. Thus, the double stoss-lee form is interpreted as a response to basal transport over abrading materials, following deposition of the clast and succeeded by modification by glacial erosion.

It is suggested that the double stoss-lee form is a diagnostic criterion for subglacial transport at the ice-bed interface and deposition by lodgement, whether it forms part of a current process of tili accumulation, or whether a re-glaciation moves surface boulders over the underlying sediments and then lodges them.

\section{ORIENTATION OF CLASTS WITH A STOSS-LEE FORM}

The spatial arrangement of clasts with a stosslee form was investigated within the area of ground moraine shown in Figure 3. It is located $400-700 \mathrm{~m}$ in front of the present ice margin and air photographs indicate that this area was deglaciated within the period 1945-60. Generally, the ground moraine slopes down-glacier but in the central part of the map the

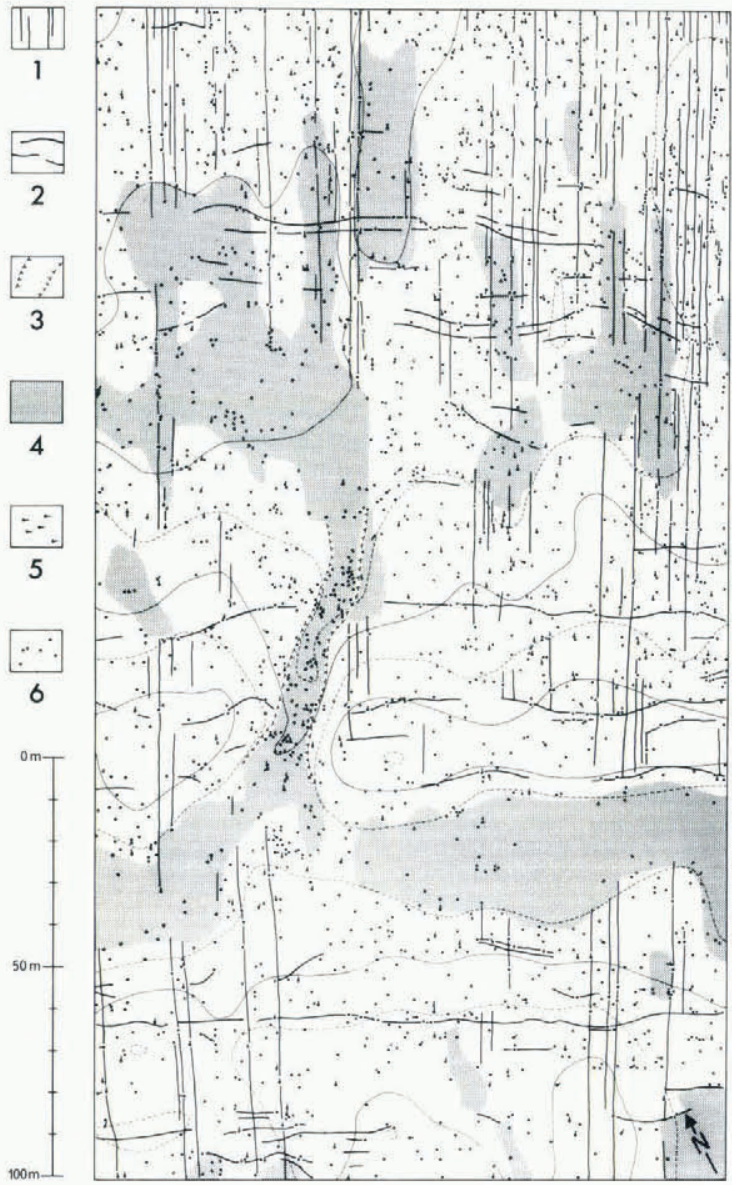

Fig. 3. Geomorphological map of part of the ground moraine in front of Mÿrdalsjökult, Iceland. contoue interval $0.5 \mathrm{~m}$.

1. Fluted moraines; 2. Annual moraines; 3. Erosion scarps; 4. Shallow depression with glacio-fl wial and downwash deposits; 5 . Clasts $(>0.3 \mathrm{~m})$ with a stoss-lee form. Lee side to the right; 6. Clasts $(>0.3 \mathrm{~m})$ without a stoss-lee form.

Ice flow is from the south-south-west. Correction for the magnetic variation $\left(22^{\circ} \mathrm{E}\right.$.).

contours show a smoothed ridge transverse to the iceflow direction. This ridge, which has a fluted and drumlinized surface and a core of dislocated drift, is interpreted as an overridden ice-marginal moraine (Krüger and Humlum, 1981). The ridge is interrupted where a former melt-water stream flowed through it. Furthermore, a series of annual moraine ridges, which trend parallel to the former locations of the ice margin, indicate that the ground moraine was exposed by frontal retreat of the glacier. The many flutes occurring within the selected area are evidence of an iceflow direction approximately south-south-west to north-north-east.

Embedded boulders larger than $0.3 \mathrm{~m}$ in diameter were selected and mapped. The presence or absence of a stoss-lee form was recorded for each clast and, if it had a stoss-lee form, its orientation relative to the ice-flow direction was indicated on the map. In this manner a total of 2199 boulders was mapped.

The spatial distribution of boulders as shown in Figure 3 demonstrates that they occur sparsely on the ground-moraine surface. In several instances, lines of boulders frequently composed of two to four boulders trend parallel to the glacier-flow direction. They probably resulted from subglacial lodgement of clasts against already lodged clasts (Boulton, [ $\left.{ }^{C} 1975\right]$; Krüger, 1979). It can be seen that boulders 
are not concentrated particularly along the annual moraines. A possible explanation is that these small ridges have been formed by glacier-induced folding of subglacially deposited till along the glacier front and not by scraping pro-glacial material together at the glacier margin (Krüger and Humlum, 1981; paper by J. Krüger in preparation).

As much as $17.3 \%$ of the mapped boulders had a stoss-lee form. The proportion of clasts with their smoothed and streamlined ends facing up-glacier within $\pm 22.5^{\circ}$ of the ice-flow direction is $72.7 \%$, showing that they can be used as indicators of ice-flow direction. Only $1.9 \%$ had their stoss-sides facing downglacier. The stoss-side orientations of 94 of the 370 stoss-lee-shaped boulders were highly variable and diverged from the ice-flow direction. However, the idea that such boulders had been re-deposited by minor advances of the ice front responsible for constructing small push moraines does not find support in the present study; only $11.7 \%$ of the boulders with divergent stoss-side orientations are located in connection with annual moraines.

\section{CONCLUSIONS}

It is suggested that the presence of clasts with a double stoss-lee form is a diagnostic criterion for subglacial deposition by lodgement. Furthermore, it is concluded that the preferred stoss-side orientation of clasts with the development of a stoss-lee form on their upper surfaces indicates the direction from which the ice came. Stoss-lee-shaped clasts with a highly variable and divergent orientation relative to the ice-flow direction have mainly been re-deposited beneath the ice and not at the ice front by minor advances of the glacier.

\section{ACKNOWLEDGEMENTS}

For financial support the author wishes to thank the Danish Natural Science Research Council and the Carlsberg Foundation. 0. Humlum, L. Pedersen, E. Lund, and H.H. Thomsen, Department of Geomorphology, University of Copenhagen, took part in the field work and discussions on the observations. To all these individuals I extend my sincere thanks. Furthermore, I am grateful to the Icelandic National Research Council for allowing me to work at the margin of Mýrdalsjökull.

\section{REFERENCES}

Boulton G.S. [ $\left.{ }^{{ }^{C}} 1975.\right]$ Processes and patterns of subglacial sedimentation: a theoretical approach. (In Wright, A.E., and Moseley, F., ed. Ice ages: ancient and modern. Liverpool, Seel House Press, p. 7-42. (Geological Jozonal Special Issue No.6.)) Boulton, G.S. 1978. Boulder shapes and grain size distribution of debris as indicators of transport paths through a glacier and till genesis. Sedimentology, Vol. 25, No. 6, p. 773-99.

Krüger, J. 1979. Structures and textures in till indicating subglacial deposition. Boreas, Vol.8, No. 3, p. 323-40.

Krüger, J., and Humlum, 0. 1981. The proglacial area of Mýrdalsjökull with particular reference to slëttjökull and Höfdabrekkujökul1: general report on the Danish geomorphological expedition to Iceland, 1977. Folia Geographica Danica, Tom. 15, No. 1.

Okko, V. 1955. Glacial drift in Iceland, its origin and morphology. Bulletin de la Commission Géologique de Fintande, No. 170.

Sharp, M.J. 1982. Modification of clasts in lodgement tilis by glacial erosion. Joumal of Glaciology, Vol. 28, No. 100, p. 475-81. 